\title{
SUBMICRO AND NANO CERAMICS AS BALLISTIC PROTECTIVE MATERIAL
}

\section{CERAMIKA SUBMIKRONOWA I NANOCERAMIKA JAKO MATERIAŁY NA OSŁONY BALISTYCZNE}

\author{
Erhardt $\mathrm{LACH}^{1}$, Thomas WOLF ${ }^{1}$, Michael SCHARF ${ }^{1}$
}

\begin{abstract}
The increasing capability of modern anti-armor threats has intensified the need for highly effective passive armor systems. Additionally, light-weight armor systems becoming more important to ensure improved strategic mobility and tactical agility for future combat systems, while maintaining crew protection. It is necessary to airlift military vehicles to remote locations in under-developed regions this requires a large weight reduction in the armor system. Ceramic armor technology offers significant advantages for meeting future protection requirements. Ceramics are effective, because of their hardness, which is considerably greater than that of other material classes, and also they are much lighter than steel. The investigation and application of ceramics against small arms threats has a long history and the ballistic performance of ceramic armors for personnel protection is very high; the principles governing these defeat mechanisms are now generally understood. However, achieving similar ceramic performance versus larger caliber, like kinetic energy (KE) penetrator threats, has long taken as a difficult challenge. This work deals with sub micro and nano ceramics for ballistic protection. Model KE penetrators have been used to investigate the protection capability.
\end{abstract}

Keywords: ballistics, ballistic protection, $\mathrm{Si}_{3} \mathrm{~N}_{4}$ ceramics, ceramic armor, $\mathrm{KE}$ penetrator

Streszczenie: Nowoczesna amunicja, o coraz większej zdolności rażenia i sile przebijania osłon balistycznych, powoduje konieczność ulepszania wysoko-efektywnych, pasywnych systemów obronnych. Celem stało się projektowanie coraz wytrzymalszych, a zarazem lżejszych osłon i pancerzy, zapewniających skuteczną ochronę żołnierzom, przy jednoczesnym zwiększeniu mobilności i zdolności taktycznych konstrukcji. Niższa waga pancerza jest szczególnie istotna, jeśli wziąć pod uwagę na jak duże odległości muszą czasem być transportowane pojazdy bojowe. Materiały ceramiczne znajdują zastosowanie w osłonach balistycznych, z powodu wysokiej twardości i małej masy, co powoduje, że pancerz kompozytowy $\mathrm{z}$ warstwą ceramiczną, będąc lżejszy i równie wytrzymały na wpływ obciążenia uderzeniowego jak jego tradycyjny odpowiednik o tej samej grubości, spełnia

\footnotetext{
${ }^{1}$ French-German Research Institute of Saint-Louis, ISL, 5, rue du Général Cassagnou, F-68301 SAINT LOUIS
} 
powyższe wymagania dotyczące nowoczesnych pancerzy. Prowadzone od lat badania nad materiałami ceramicznymi w zakresie ich stosowalności jako elementu pancerza lub indywidualnej osłony balistycznej, pozwoliły na zrozumienie zasad zachowania materiałów ceramicznych pod obciążeniem dynamicznym. Jednakże, opis zachowania tych materiałów po uderzeniu amunicji o dużym kalibrze, jak np. pocisk podkalibrowy (ang. kinetic energy (KE) penetrator) stanowi nadal naukowe wyzwanie. W niniejszej pracy zamieszczono rozważania dotyczące materiałów ceramicznych o submikro- i nanostrukturze, mających zastosowanie dla ochrony balistycznej, w szczególności przedstawia się wyniki badań zachowania materiałów ceramicznych pod wpływem uderzenia pociskami podkalibrowymi.

Słowa kluczowe: balistyka, osłona balistyczna, pancerz ceramiczny, pocisk podkalibrowy, ceramika $\mathrm{Si}_{3} \mathrm{~N}_{4}$

\section{INTRODUCTION}

Future combat systems should possess improved strategic mobility and tactical agility, while maintaining overwhelming firepower and crew protection. Therefore, armored vehicles have to be lighter, faster, and more agile than the cold war era main battle tanks. Tactical mobility involving airlift of vehicles requires a significant weight reduction. Since the 1950 s the main alternatives to steel have been aluminium alloys, an alloy with reduced density. Light-weight metals, like magnesium and aluminium alloys, have one main disadvantage their reduced strength and hardness compared to steels. Ceramic materials can provide increased hardness and strength.

Threats for armored vehicles are kinetic energy (KE)-penetrators or armor piercing (AP)bullets, shaped charges, explosively formed penetrators (EFP) and fragments from mines and improvised explosive device (IED) in combination with blast waves.

One of the most effective threats to defeat main battle tanks are kinetic energy (KE) or longrod penetrators. Penetrators are made of high strength, high density materials, such as W sintered alloy or depleted $\mathrm{U}$, having densities near $18 \mathrm{~g} / \mathrm{cm}^{3}$ and moderate hardness, good toughness and ductility. At ordnance velocity they yield a kinetic energy in excess of $10^{6} \mathrm{~J}$ and creating high energy density per unit area of a target impacted [1,2]. The highest L/D aspect ratio may exceed 30:1. The calibers used for long rods range depending on their size from $20 \mathrm{~mm}$ up to $140 \mathrm{~mm}$. The impact velocity amounts from 1300 to $1600 \mathrm{~m} / \mathrm{s}$.

The aim of this work is to investigate the ballistic protection capability of ceramic materials. It is well known that the hardness of conventional ceramic materials has a strong erosive effect on long rod penetrators. In general both hardness and strength of materials could be improved by decreasing grain sizes, because it has a strong effect on the mechanical behavior as it is described by the Hall-Petch relation [3,4]. For that reason sub micro and nano ceramics have been investigated on its ballistic protection capability in this work.

\section{CERAMIC MATERIALS}

\subsection{SUBMICRO $\mathrm{Al}_{2} \mathrm{O}_{3}$ CERAMICS}

The plates have been purchased by Fraunhofer Institut Keramische Technologien und Systeme, IKTS, Dresden [5-9]. High purity $\mathrm{Al}_{2} \mathrm{O}_{3}$ powders with different grain sizes were used to produce square shaped plates with a side length of $100 \mathrm{~mm}$ and a thickness of $5 \mathrm{~mm}$ 
for terminal ballistic tests. Tiles $a, b$ and $c$ in Table 1 have been shaped by gel casting and tile $d$ by pressing of spray granules. Then the tiles have been pressure less sintered at different temperatures and for different holding times. The sintering temperature and holding time, grain sizes, density and mechanical properties are compiled in Table 1.

The objective was to test different hardness of the material and strengths measured with the 4point bending test, because the ballistic tests should provide information on the mechanical properties are significant for ballistic protection capability. The hardness of the studied $\mathrm{Al}_{2} \mathrm{O}_{3}$ ceramics is increasing with decreasing grain size, i.e. it follows the Hall-Petch relation as Table 1 shows, whereas the bending strength is influenced by the manufacturing method, which influences the residual faults and the inter-grain phases.

Table 1. Investigated $\mathrm{Al}_{2} \mathrm{O}_{3}$ ceramic with different grain sizes and mechanical properties

\begin{tabular}{|c|c|c|c|c|c|c|}
\hline Specimen & $\begin{array}{c}\text { Shaping } \\
\text { method }\end{array}$ & $\begin{array}{c}\text { Sintering temperature } \\
\text { (holding time) } \\
{ }^{\circ} \mathrm{C}\end{array}$ & $\begin{array}{c}\text { Mean grain } \\
\text { size } \\
\mu \mathrm{m}\end{array}$ & $\begin{array}{c}\text { Density } \\
\mathrm{g} / \mathrm{cm}^{2}\end{array}$ & $\begin{array}{c}\text { Hardness } \\
\text { HV10 }\end{array}$ & $\begin{array}{c}\text { Bending } \\
\text { strength } \\
\mathrm{MPa}\end{array}$ \\
\hline $\mathrm{a}$ & Gel casting & $1250(2.5)$ & 0.6 & 3.97 & 1977 & 557 \\
\hline $\mathrm{b}$ & " & $1550(2.5)$ & 3.76 & 3.96 & 1725 & 470 \\
\hline $\mathrm{c}$ & " & $1725(5)$ & 9.82 & 3.97 & 1543 & 350 \\
\hline $\mathrm{d}$ & $\begin{array}{c}\text { Pressing } \\
\text { spray granule }\end{array}$ & $1380(2)$ & 0.91 & 3.96 & 1908 & 345 \\
\hline
\end{tabular}

For the hardness measurements compiled in Table 1 the Vickers hardness HV10 was used. The necessity to use the macro hardness indenter for determining the hardness is explained in reference [10]. The diagram in Figure 1 shows clearly that the macro hardness is decreasing strongly for grain sizes smaller than $0.5 \mu \mathrm{m}$. The reason for this is the massive appearance of amorphous inter-grain phases for grain sizes smaller than $500 \mathrm{~nm}$. In references [11,12] is reported about ballistic tests using small caliber armor piercing (AP) bullets. The results are showing that the ballistic protection capability will decrease for grains having a smaller diameter than $500 \mathrm{~nm}$. Therefore in this study ballistic tests with $\mathrm{Al}_{2} \mathrm{O}_{3}$ ceramic having a grain size of less than $500 \mathrm{~nm}$ were excluded. It was preferred to include plates with similar hardness, but different bending strength in order to get information on the influence of strength.

A metallographic investigation was carried out for all tiles. The microstructure of the four different plates is shown in Figures $2 \mathrm{a}-\mathrm{d}$. The micrographs reveal pores in the microstructure of two plates (Figures $2 \mathrm{~d}$ and $\mathrm{c}$ ). In the case of shock waves pores are starting points for the formation of cracks resulting in a prior damage of the ceramic plates. 


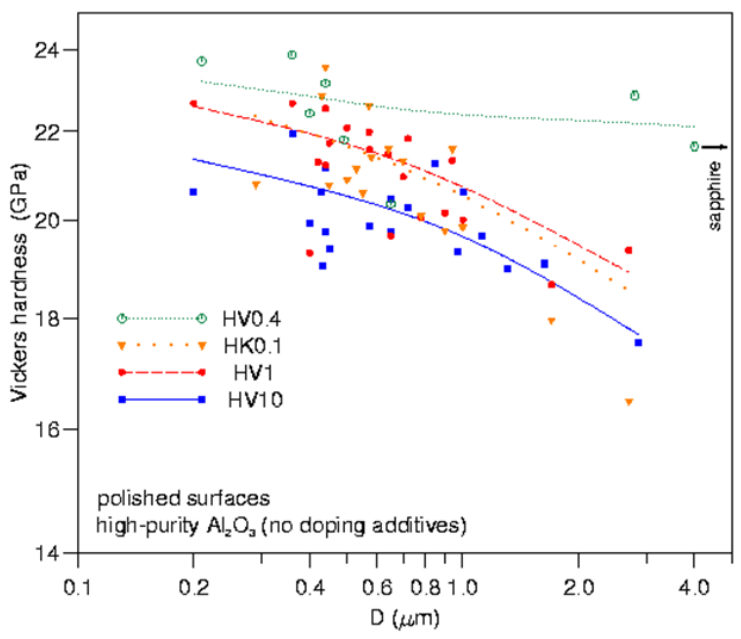

Figure 1. Vickers hardness of $\mathrm{Al}_{2} \mathrm{O}_{3}$ ceramic as a function of grain size [10]



Figure 2. Microstructure of the $\mathrm{Al}_{2} \mathrm{O}_{3}$ plates investigated (Table 1).

The grain size is increasing from left to right: a) $0.6 \mu \mathrm{m}$, b) $3.76 \mu \mathrm{m}$, c) $9.82 \mu \mathrm{m}$ and d) $0.91 \mu \mathrm{m}$

\subsection{FINE AND NANO GRAINED $\mathrm{Si}_{3} \mathrm{~N}_{4}$ CERAMICS}

$\mathrm{Si}_{3} \mathrm{~N}_{4}$ ceramic are well known for its mechanical properties and is taken into account as valve material for gasoline engines. In this work $\mathrm{Si}_{3} \mathrm{~N}_{4}$ ceramics possessing a nano grained 
micro structure were investigated on their ballistic protection capability. A conventional $\mathrm{Si}_{3} \mathrm{~N}_{4}$ ceramic produced in an industrial scale with fine grain sizes in the micrometer level was also investigated for comparison to the nano sized $\mathrm{Si}_{3} \mathrm{~N}_{4}$.

The nano $\mathrm{Si}_{3} \mathrm{~N}_{4}$ was purchased from Fraunhofer Institute Keramische Technologien und Systeme, IKTS (Dresden) and the fine grained $\mathrm{Si}_{3} \mathrm{~N}_{4}$ from Sintec Company (Buching, Germany). The chemical composition is shown in Table 2.

Table 2. Chemical composition of studied $\mathrm{Si}_{3} \mathrm{~N}_{4}$ ceramics in weight-\%

\begin{tabular}{|c|c|c|c|}
\hline & $\mathrm{Al}_{2} \mathrm{O}_{3}$ & $\mathrm{Y}_{2} \mathrm{O}_{3}$ & $\mathrm{Si}_{3} \mathrm{~N}_{4}$ \\
\hline nano $\mathrm{Si}_{3} \mathrm{~N}_{4}$ & 8 & 6 & bal. \\
\hline fine grained $\mathrm{Si}_{3} \mathrm{~N}_{4}$ & 6 & 4 & bal. \\
\hline
\end{tabular}

The Vickers hardness of the nano $\mathrm{Si}_{3} \mathrm{~N}_{4}$ and the fine grained $\mathrm{Si}_{3} \mathrm{~N}_{4}$ measured at room temperature amounts to $1544 \mathrm{HV} 10$ and $1353 \mathrm{HV} 10$, respectively. $\mathrm{K}_{\mathrm{IC}}$ values were determined by the method of Antis [13] and amounts to $2.5 \mathrm{MPam}^{1 / 2}$ for the nano $\mathrm{Si}_{3} \mathrm{~N}_{4}$ and 4.9 $\mathrm{MPam}^{1 / 2}$ for the conventional $\mathrm{Si}_{3} \mathrm{~N}_{4}$.

Depending on the columnar grain growth of the conventional fine grained ceramics the $\mathrm{K}_{\mathrm{IC}}$ value is twice of that of the nano ceramic. The nano ceramics were sintered at a significantly lower temperature than the conventional ceramics in order to avoid the anisotropic coarsening of the grains. A fine grained microstructure results in a higher hardness. Metallographic pictures can be seen in Figures $3 a$ and $b$.

Contrary to the $\mathrm{Al}_{2} \mathrm{O}_{3}$ ceramic, which has been sintered in the solid state, the $\mathrm{Si}_{3} \mathrm{~N}_{4}$ ceramics was produced by a liquid phase sintering process. In reference [14] it is shown that the increase in hardness for liquid phase sintered ceramics is relatively small, because of the huge amount of amorphous grain interface phases.

a)

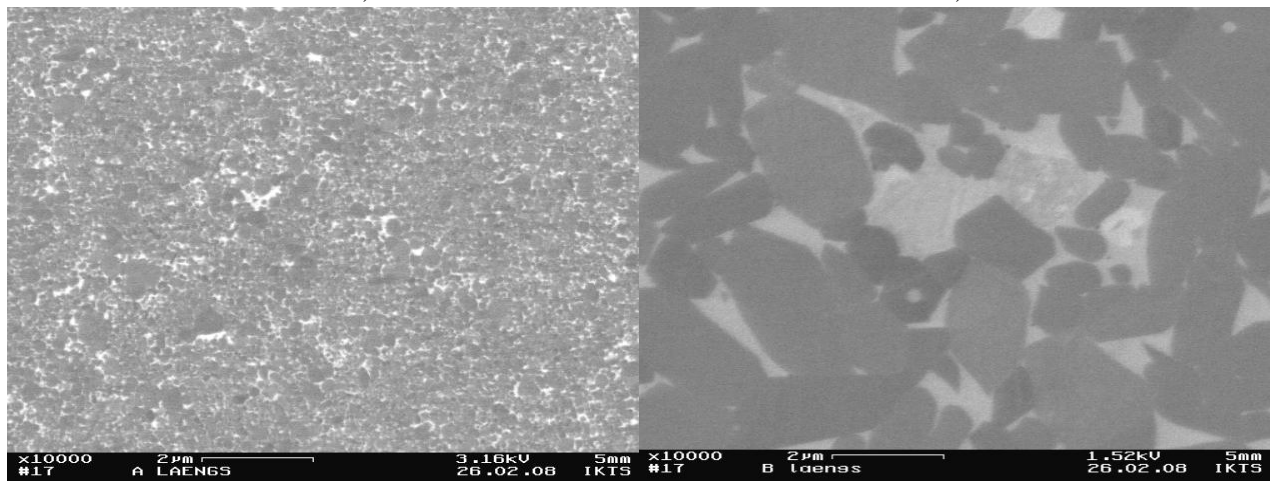

Figure 3. Micro structure of $\mathrm{Si}_{3} \mathrm{~N}_{4}$ ceramics, grain size a) $90 \mathrm{~nm}$ and b) $6 \mu \mathrm{m}$

The compression strength of the $\mathrm{Si}_{3} \mathrm{~N}_{4}$ ceramic was tested by 'the ball on three balls test' developed at the University of Leoben [15-17]. Figure 4 presents the results of the tests. The strength of the fine grained $\mathrm{Si}_{3} \mathrm{~N}_{4}$ ceramic is significantly increased compared to that of nano $\mathrm{Si}_{3} \mathrm{~N}_{4}$ ceramics. 




Figure 4. Compression strength of $\mathrm{Si}_{3} \mathrm{~N}_{4}$ ceramics investigated

\section{BALLISTIC TESTS}

\subsection{EXPERIMENTAL PROCEDURE}

The ballistic protection capability of the ceramics was investigated using the DOP (Depth Of Penetration) test. Therefore the penetration in a target consisting of the studied material and a backing (Figures 5 and 6) will be compared to the residual penetration in a semi infinite reference target (Figures $7 a$ and $b$ ). This test is suitable for an estimation of the maximal ballistic protection potential and allows a direct comparison of materials resulting in a materials ranking. The backing and the reference target have to be of the same material.

Figure 5 illustrates schematically the design of the utilized target design $0^{\circ}$ NATO. An armor steel of medium tensile strength (1000 MPa) was chosen as backing material for the ceramic plates and also as reference material for comparison. Steel was given preference over aluminum due to its higher stiffness. The ballistic tests were performed using a $\mathrm{W}$ heavy metal rod with the following geometry: $4 \mathrm{~mm}$ in diameter and $60 \mathrm{~mm}$ in length, respectively. The impact velocity amounts to $1660 \mathrm{~m} / \mathrm{s}$.

The $\mathrm{Al}_{2} \mathrm{O}_{3}$ ceramic tiles were only $5 \mathrm{~mm}$ thick. Therefore two of them were used for the ballistic tests. The $\mathrm{Si}_{3} \mathrm{~N}_{4}$ tiles had a thickness of $20 \mathrm{~mm}$. Only one of these tiles was used for the DOP tests.

Flash X-ray photographs have been taken from every test in order to control the yaw angle of the rod before occurrence of the impact (Fig. 8). The parameters for analyzing the results obtained by the DOP test are schematically indicated in Figures $7 \mathrm{a}$ and b. Reference target 
and backing are consisting of the same steel alloy. The abbreviations in Figures $7 \mathrm{a}$ and $\mathrm{b}$ mean $\rho_{\text {ref }}=$ density of backing and reference target, $\mathrm{P}_{\text {ref }}=$ penetration in the reference target, $\mathrm{P}_{\text {res }}=$ penetration in the backing, $\mathrm{t}_{\mathrm{z}}$ and $\rho=$ thickness and density of materials investigated, respectively.

These data will be measured at the target and used to evaluate the results using equations (1) - (3). The equivalence factor (F) considers only the studied material and therefore the residual penetration in the backing is subtracted from penetration of the reference target. $F_{\mathrm{s}}$ indicate the influence on the volume and $F_{m}$ on the mass of armor. $F$ summarizes both the $F_{m}$ and $F_{s}$ values. In these equations only the protective property of the studied material will be taken into consideration. Hence, the F values are directly related to the materials investigated.

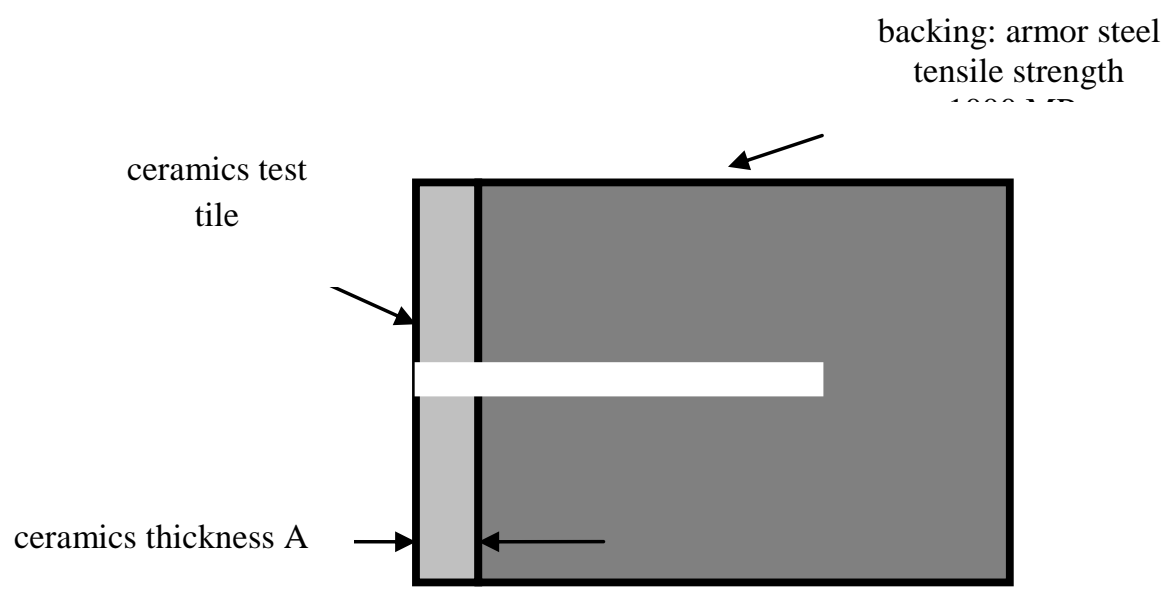

Figure 5. Target configuration $\left(0^{\circ} \mathrm{NATO}\right)$ for testing the ceramics tiles

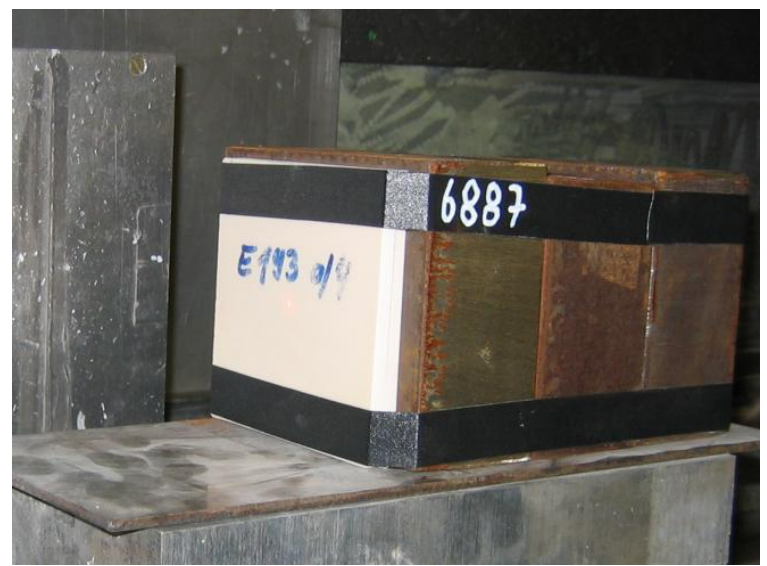

Figure 6. Photograph of the target prior to the impact test 


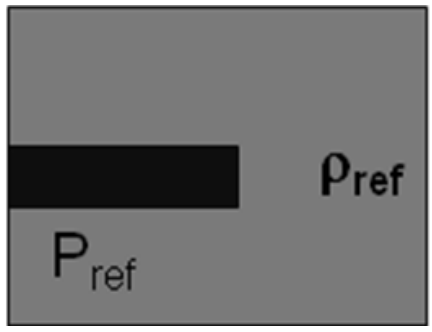

reference target $\uparrow$

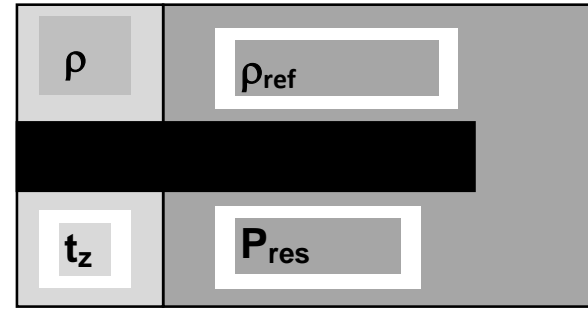

$\uparrow$ studied materials

$\uparrow$ backing

b)

Figure 7. Parameter for evaluation of the ballistic test. a) reference target $\left(\mathrm{P}_{\text {ref }}=\right.$ penetration in the reference target, $\rho=$ density of the reference target $), b)$ target design consisting of backing and test materials $\left(\mathrm{P}_{\text {res }}=\right.$ penetration in the backing, $\rho_{\text {ref }}=$ density of the backing, $t_{z}=$ thickness of studied materials, $\rho=$ density of the studied materials

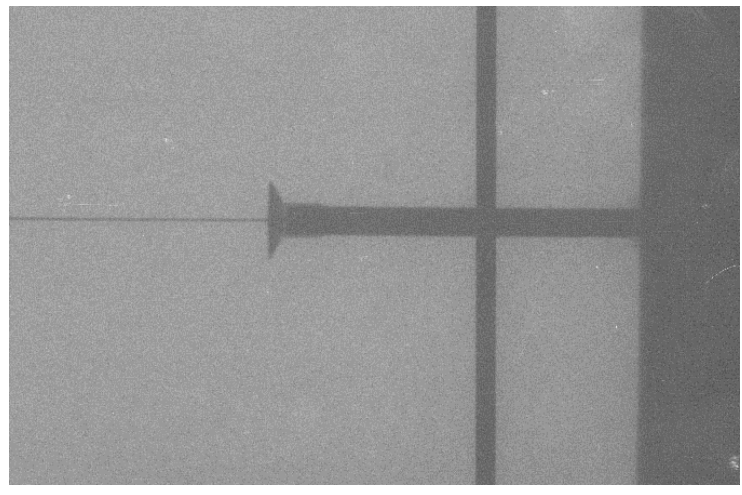

Figure 8. X-ray photograph of the impact

$$
\begin{gathered}
F_{m}=\frac{\left(P_{r e f}-P_{r e s}\right) \cdot \rho_{r e f}}{t_{z} \cdot \rho} \\
F_{s}=\frac{\left(P_{r e f}-P_{r e s}\right)}{t_{z}} \\
F=F_{m} \cdot F_{s}
\end{gathered}
$$

\subsection{RESULTS OF BALLISTIC TESTS WITH $\mathrm{Al}_{2} \mathrm{O}_{3}$}

The results evaluated from equations (1)-(3) are graphically displayed in Figure 9. $\mathrm{F}_{\mathrm{m}}$ and $\mathrm{F}_{\mathrm{s}}$ values are increasing with increasing hardness or with decreasing grain size in the range of the studied parameters. The most significant gain in ballistic protection capability is achieved for a grain size of $0.6 \mu \mathrm{m}$. No significant effect of the bending strength on the ballistic 
property had been observed.

The F values for plate $\mathrm{c}$ in table 1 (1543 HV10) increased slightly as expected due to its hardness. Controlling the flash X-ray revealed that the rod exceeds the horizontal line about $1.3^{\circ}$. This slightly increases the ballistic result.

As shown in references $[11,12]$ the macro hardness is decreasing for grain sizes smaller than $0.5 \mu \mathrm{m}$ and in the same way the protection capability decreases. Hence, it could be concluded from the experimental results that a maximum in ballistic protection capability is reached at the smallest grain size without massive amorphous inter-grain phases.

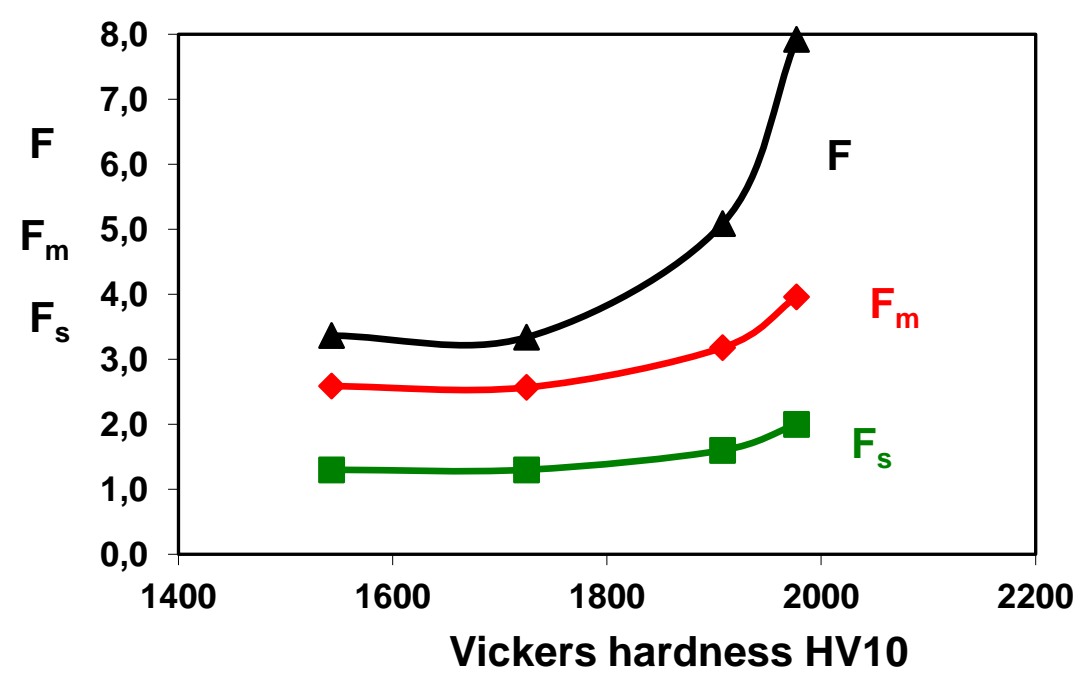

Figure 9. Results of the ballistic tests on $\mathrm{Al}_{2} \mathrm{O}_{3}$ evaluated with equations (1) - (3)

a)

b)



Figure 10. SEM micrographs of fractured $\mathrm{Al}_{2} \mathrm{O}_{3}$, mean grain size a) $0.6 \mu \mathrm{m}$ and b) $9.82 \mu \mathrm{m}$

Two micrographs of fracture surfaces are shown in Figures 10a and b. They are a feature of the smallest a) and the biggest grain size b). It is obvious that the nano grained microstructure in Figure 10a generates more deflection of cracks due to the increased number of grain boundaries than the microstructure in Figure 10b does. But the cleavage fracture is 
characterized as a low energy fracture and therefore the energy absorption is negligible. Hence, it does not affect the performance of the ballistic protection.

\subsection{RESULTS OF BALLISTIC TESTS WITH $\mathrm{Si}_{3} \mathrm{~N}_{4}$}

Figure 11 demonstrates the results of the ballistic tests with $\mathrm{Si}_{3} \mathrm{~N}_{4}$. The results reveal that the macro hardness is the most important parameter and confirm the results received from the tests with $\mathrm{Al}_{2} \mathrm{O}_{3}$ shown in Figure 9. The macro hardness between fine grained and nano $\mathrm{Si}_{3} \mathrm{~N}_{4}$ ceramic does not differ strongly. This also affects the ballistic results. The increase of the $\mathrm{F}$ values is not as strong as observed for the high purity $\mathrm{Al}_{2} \mathrm{O}_{3}$ ceramics. This is well understood and depends on the increased mass of inter-grain phases due to the liquid phase sintering process, which causes a slightly increase in hardness only. Neither the compression strength nor the $\mathrm{K}_{\mathrm{Ic}}$ value has any influence on the ballistic results.

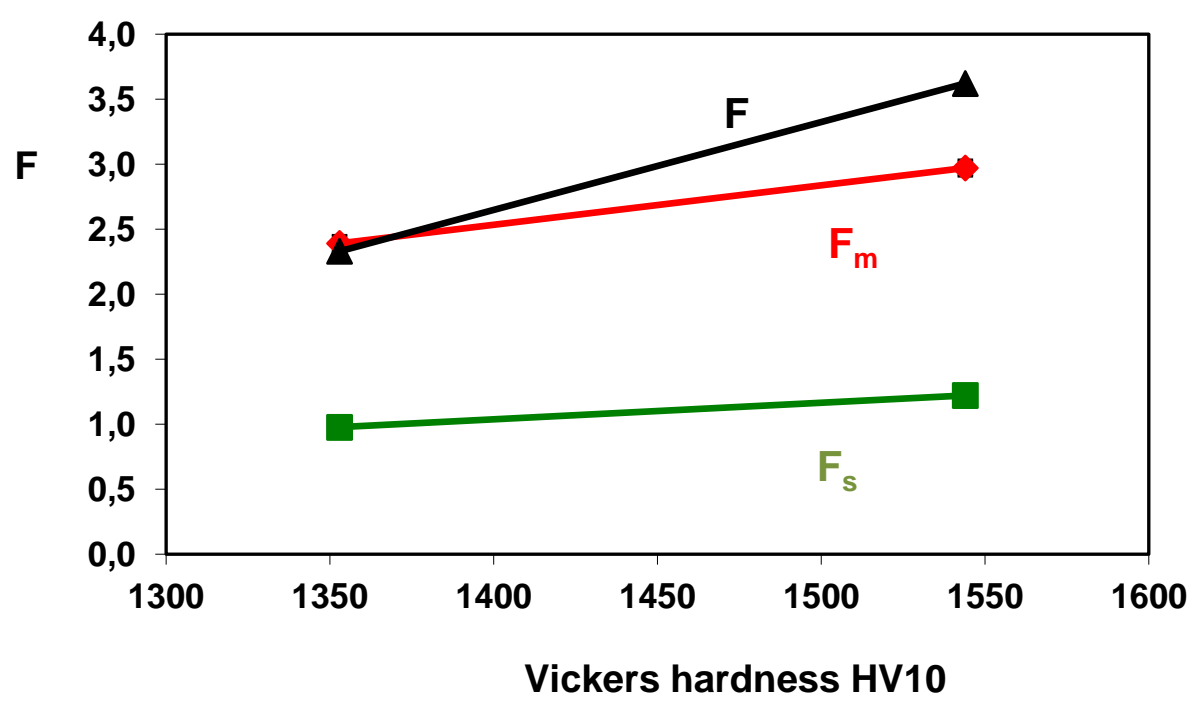

Figure 11. Ballistic tests with $\mathrm{Si}_{3} \mathrm{~N}_{4}$ possessing different hardness

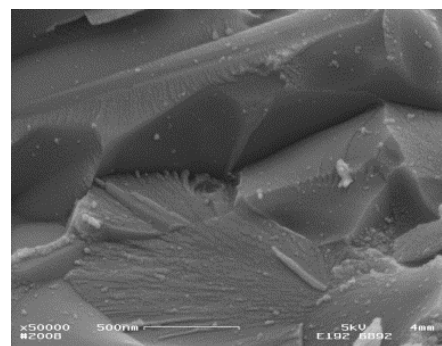

a)

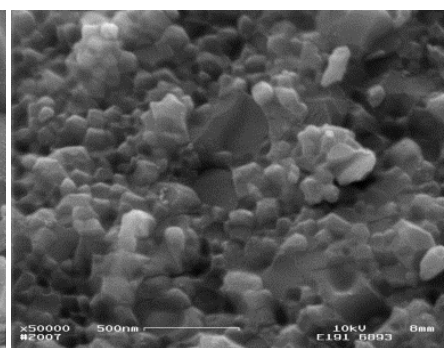

b)

Figure 12. SEM micrographs of fractured $\mathrm{Si}_{3} \mathrm{~N}_{4}$, mean grain size a) $6 \mu \mathrm{m}$ and b) $90 \mathrm{~nm}$ 
Two micrographs of $\mathrm{Si}_{3} \mathrm{~N}_{4}$ fracture surfaces are shown in Figures 12a and b. Furthermore, it is obvious that the nano grained microstructure must generate more deflection of cracks due to the increased grain boundaries. Crack initiation and propagation have only a negligible influence on the ballistic protection capability.

\section{CONCLUSION}

The ballistic results prove a strong dependency on the macro hardness assuming that a target configuration like in this investigation is used. The results show also that a ceramic material should be used which could be sintered in the solid state, because liquid phase sintering increases the amorphous phases between the crystalline grains and prevents a significant increase of the macro hardness.

For high purity $\mathrm{Al}_{2} \mathrm{O}_{3}$ ceramics the fracture of amorphous inter-grain phases in the micro structure is becoming important if the grain size goes below of about $0.5 \mu \mathrm{m}$. The $\mathrm{Al}_{2} \mathrm{O}_{3}$ ceramics investigated shows a significant decrease in hardness when decreasing the grain size from $0.5 \mu \mathrm{m}$ on downwards. As the results are show the ballistic protection capability depends directly on the macro hardness. This is not a general statement, but valid for the ceramic materials investigated in this work.

No significant influence of compression strength and $\mathrm{K}_{\mathrm{Ic}}$ values on the ballistic behavior of the studied ceramic materials could be found.

\section{ACKNOWLEDGEMENT}

The authors wish to thank her colleague, Dr. Teresa Fras, for translating the abstract into the Polish language.

\section{LITERATURE}

[1] ZUKAS J. A., High Velocity Impact Dynamics, Wiley, New York, 1990.

[2] ROSENBERG, Z., DEKEL, E., Terminal Ballistics, Springer, Heidelberg, 2012.

[3] HALL, E. O., The deformation and ageing of mild steel. 3. Discussion of results. Proceedings of the Royal Society of London, Series B, 64, 1951, 747-753.

[4] PETCH, N. J., The Cleavage Strengt of Polycrystalls. Journal of the Iron and Steel Institute, 174, 1953, 25-28.

[5] HONGWEI M., KRELL A., Synthesis and Processing of $\mathrm{Nano} \alpha-\mathrm{Al}_{2} \mathrm{O}_{3}$ Powder, Key Engineering Materials Vols. 206-213, 2002, pp. 43-46.

[6] KRELL A., Fracture Origin and Strength in Advanced Pressure Less Sintered Alumina, J. Am. Ceram. Soc., 81 (7), 1998, pp. 1900-1906.

[7] KRELL A. , BLANK P., The influence of shaping method on the grain size dependence of strength in dense submicrometer alumina, J. of the European Ceramic Society 16, 1996, pp. 1189-1200.

[8] KRELL A., Improved hardness and hierarchic influences on wear in submicron sintered alumina, Materials Science and Engineering A, 209, 1996, pp. 156-163.

[9] KRELL A. and BLANK P., Grain Size Dependence of Hardness in Dense Submicrometer Alumina, J. Am. Ceram. Soc., 78 (4), pp. 1118-1120.

[10] KRELL A., A new look at the influences of load, grain size and grain boundaries on the room temperature hardness of ceramics, Int. Journal Refractory Metals \& Hard Materials, 16, 1998, pp 331 - 335.

[11] STRASSBURGER E., SENF H., ROTHENHÄUSLER H., LEXOW B., KRELL A. Influence of Grain Size and Microstructure on the Ballistic Resistance of Alumina, Proc. $18^{\text {th }}$ Int. Symp. On Ballistics, San Antonio, TX, 1999.

[12] STRASSBURgER E., LEXOW B., KRELL A., Ceramic Armor with Submicron Alumina against AP Projectiles, Ceram. Trans. 134 [1-2], 2001, 83-90.

[13] ANTIS G. R., J. Am. Ceram. Soc. 64, 1981, pp. 533-538

[14] KAYSER et al., Nanostructured Materials 8, 1997, 4, pp. 489-497 
[15] DANZER R., HARRER W., SUPANCIC P., LUBE T., WANG Z. AND BÖRGER A., J. of the European Ceramic Society 27 (2007), pp. 1481-1485.

[16] BÖRGER A., SUPANCIC P. AND DANZER R., J. of the European Ceramic Society 24 (2004), pp. 29172928.

[17] BÖRGER A., SUPANCIC P. AND DANZER R., J. of the European Ceramic Society 22 (2002), pp. 14251436. 